\title{
Analisis Potensi Bahan Pakan Lokal Untuk Pengembangan Ternak Sapi Potong di Sumatera Barat
}

\author{
F. Madarisa, I. Iskandar dan Deswita Andelina \\ Junusan Produksi Ternak Fakultas Peternakan Universitas Andalas, Padang
}

\begin{abstract}
Using secondary data, a survey was conducted to assess the availability of potentially beef cattle feed in West Sumatra province. Two methods were applied to analyze the collecied data; 1) stpporting capacity index (IDD) developed by Livestock Research Institute at Ciawi Bogor which also legally accepted as an instrument to determine regional capacity in supporting cattle feed. 2). Nell and Rollinson method which has been applied in Indonesia since 1974 supported by UNDP. Resulst showed that by the first method (IDD), West Sumatra has I,888,032,77 ton and 459,04I,026 ton potential feed from agriculture and agricultural by products respectively in 2007. The second Nell and Rollinson method confirmed that West Sumatra has 33,286,255.20 ton from grass production and 588,638.72 ton agricultural by products. Compared between the West Sumatra regional capacity to support beef cattle as $1,028,935.9$ animal unit, and ruminants population as $446,072.7$ animal unit, there is an additional capacity to keep ruminants as 562,863.2 animal unit. Based on the cattle contribution as $63 \%$ to total population, West Sumatra could increase its support to cattle population by $355,110.6$ animal unit. Nell and Rollinson showed an optimistic figure, namely 1,408,892 animal unit for cattle.
\end{abstract}

Key words: local feed, West Sumatra, supporting capacity index

\section{Peadahuluan}

Ternak sapi adalah salah satu ternak ruminansia yang banyak dipelihara oleh para petani di Sumatera Barat. Kebutuhan akan produksi usaha peternakan (daging, telur, susu) tiap tahun terjadi peningkatan. Hal ini disebabkan karena terjadinya perubahan sosial, budaya, tingkat pendidikan, era globalisasi, dan peningkatan teknologi informasi yang mempengaruhi pola hidup dan pola konsumsi masyarakat. Sehingga semakin meningikat kesadaran akan kebutuhan gizi yang bersumber dari protein hewani. Perubahan tersebut dapat dilihat berdasarkan laporan dari Dinas Peternakan Propinsi . Sumatera Barat dalam kurun waktu 5 tahun belakangan $(2001-2005)$ telah terjadi persentase penurunan populasi ternak sapi menjadi $(1,024 \%)$ pertahun, sementara persentase jumlah pemotongan terjadi peningkatan menjadi $(3,59 \%)$.

Usaha pengembangan peternakan sapi potong di Sumatera Barat sangat berpotensi sekali. Hal ini dapat terlihat dari jumlah pemasukan dan pengeluaran sapi di Sumatera tengah tahun 2005. Selisih antara pemasukan dan pengeluaran sapi terlihat jelas antara lain Sumatera Barat sebesar 7.500 ton, Riau sebesar 15.754 ton dan Jambi sebesar 9.418 ton. Dari selisih jumlah pemasukan dan pengeluaran diatas terlihat bahwa ketergantungan Riau dan Jambi 
terhadap sapi potong sangat tinggi, sementara Sumatera Barat berpotensi untuk mengisi kebutuhan ke 2 (dua) propinsi tersebut. (Dinas Peternakan Propinsi Sumatera Barat, 2005).

Usaha peningkatan produksi peternakan dapat dilakukan dengan jalan memberikan pakan yang bermutu baik. Kenyataan menunjukkan bahwa terbatasnya ketersediaan pakan atau hijauan pada ternak ruminansia merupakan salah satu masalah yang serius dalam usaha meningkatkan produksi. $\mathrm{Hal}$ ini disebabkan karena banyaknya lahan yang dipergunakan untuk perumahan, industri, perkebunan, dan pertanian tanaman pangan sehingga lahan untuk menanam hijauan semakin terbatas. Untuk mengatasi masalah diatas perlu dicari bahan pakan alternatif yang mudah didapat dan tersedia sepanjang tahun.

Di Sumatera Barat potensi lahan untuk pengembangan usaha peternakan sapi potong sangat besar hal ini terlihat dari luas lahan budidaya untuk tanaman bahan pakan di Sumatera Barat sebesar 23.190,51 $\mathrm{km}^{2}$.

Merujuk pada latar belakang diatas, tujuan penelitian ini ádalah:

1. Mengetahui potensi bahan pakan temak sapi yang ada di Sumatera Barat.

2. Untuk mengetahui apakah ketersediaan bahan pakan yang ada mencukupi kebutuhan sapi potong di Sumatera Barat.

\section{Metode Penelitian}

Penelitian ini akan dilaksanakan untuk sehuruh Kabupaten Kota di Sumatera Barat dan berlangsung sejak Agustus 2007 sampai Oktober 2007.
Penelitian menggunakan data sekunder yang diperoleh dari instansiinstansi terkait seperti Dinas Peternakan, Biro Pusat Statistik, Dinas Tanaman Pangan dan Holtikultura, Dinas Pertanahan.

\section{Variabel Penelitian dan} Pengukuranaya

1. Demografi dan Topografi Wilayah Sumatera Barat.

2. Ketersediaan pakan berdasarkan luas lahan pertanian, tanaman pangan dan limbah hasil pertanian di Sumatera Barat.

3. Jumlah ternak sapi, kerbau, kambing, domba menurut daerah.

\section{Analisis Data}

1. Analisis Deskriptif

2. Analisa Potensi Bahan Pakan (Balai Penelitian Ternak Ciawi Bogor). Indeks Daya Dukung (IDD), yaitu kemampuan Wilayah dan Kapasitas Penambahan Ternak Ruminansia.

Dalam hubungan itu, IDD mempunyai 4 (empat) kriteria :

1. Wilayah sangat kritis, yaitu wilayah dengan IDD $\leq 1$

2. Wilayah Kritis, yaitu wilayah dengan $\mathrm{IDD}<1-1,5$

3. Wilayah Rawan, yaitu wilayah dengan IDD $=2$

4. Wilyah Aman, yaitu wilayah dengan IDD $>2$

IDD $=\frac{\text { Total potensi pakan tersedia }}{\text { Total Kebutuhan Pakan }}$

Total potensi pakan yang tersedia $(B K C)=$ Jumlah pakan asal limbah pertanian (Tabel 1) + jumlah produksi hijauan alami menurut penggunaan lahan (Tabel 2).

Total kebutuhan pakan $($ BKC) $=$ Populasi ternak (ST) $\times 1,4$ ton berat kering cerna. 
Tabel 1. Pakan Asal Limbah Pertanian

\begin{tabular}{|c|c|c|c|c|c|}
\hline No. & $\begin{array}{l}\text { Jenis Limbah } \\
\text { Tanaman Pangan }\end{array}$ & $\begin{array}{c}\text { Produksi } \\
\text { Tanaman } \\
\text { (Ton/Thn) }\end{array}$ & $\begin{array}{l}\text { Produksi } \\
\text { Limbah } \\
\text { (Ton/Thn) }\end{array}$ & Daya Cerna & $\begin{array}{l}\text { Produksi } \\
\text { Limbah } \\
\text { BKC Ton }\end{array}$ \\
\hline 1. & Padi Sawah & - & (c) & 0,20 & (d) $\times$ (e) \\
\hline 2. & Padi Ladang & - & (c) $\times 2$ & 0,20 & (d) $x(e)$ \\
\hline 3. & Jagung & - & (c) $\times 2$ & 0.20 & (d) $x(e)$ \\
\hline 4. & Kedelai & - & (o) $\times 2$ & 0,25 & (d) $x$ (e) \\
\hline 5. & Kacang Hijau & - & (c) $\times 2$ & 0,25 & (d) $x$ (e) \\
\hline 6. & Kacang Taanah & - & (c) $\times 2$ & 0,25 & (d) $x(c)$ \\
\hline 7. & Ubi Jalar & - & (c) $/ 6 \times 0,25$ & 0,30 & (d) $\times(e)$ \\
\hline 8. & Ubi Kayu & - & (c) $/ 4 \times 0,25$ & 0,30 & (d) $x(c)$ \\
\hline
\end{tabular}

Keterangan : $\mathrm{BKC}=$ Berat Kering Cerna

Sumber : Balitnak Ciawi Bogor (2006)

Tabel 2. Pakan Hijauan Alami Menurut Penggunaan Lahan

\begin{tabular}{|c|c|c|c|c|c|}
\hline No. & Penggunaan Lahan & $\begin{array}{l}\text { Luas } \\
(\mathrm{Ha})\end{array}$ & $\begin{array}{c}\text { Produktifitas Pakan } \\
\text { Hijauan } \\
\text { (Ton/Ha/Thn) }\end{array}$ & $\begin{array}{c}\text { Faktor } \\
\text { Konservasi }\end{array}$ & $\begin{array}{c}\text { Produksi } \\
\text { (Ton/BKC/Ha/ } \\
\text { Thn) }\end{array}$ \\
\hline 1 & Sawah & - & 1,250 & 1 & c x d x e $x 0,25$ \\
\hline 2 & Lahan Kering & - & 2,975 & 2 & $c x d x \in x 0,25$ \\
\hline \multirow[t]{6}{*}{3} & Perkebunan & & & & \\
\hline & - Karet & - & 2,000 & 2 & cxd $x$ ex 0,25 \\
\hline & - Sawit & - & 2,000 & 2 & $c x d x \in x 0,25$ \\
\hline & - Kelapa Dalam & - & 5,000 & 2 & $c x d x \in \times 0,25$ \\
\hline & - Cengkeh & - & 2,500 & 2 & $c \times d x \in \times 0,25$ \\
\hline & - Vanili & - & 0,750 & 2 & c $x d x$ e $x 0,25$ \\
\hline 4 & Pekarangan & - & 0,530 & 2 & $\mathrm{cxd} x$ ex 0,25 \\
\hline 5 & Tegalan/Kebun & - & 2,875 & 1 & c $x d x$ e $x 0,25$ \\
\hline 6 & Ladang/P.rumput & - & 5,000 & 1 & $c x d x \in x 0,25$ \\
\hline 7 & Hutan Rakyat & - & 0,600 & 1 & $c \times d x \in \times 0,25$ \\
\hline 8 & Pagar Hidup & - & 0,500 & 1 & $c x d x \in x=0,25$ \\
\hline 9 & Lain-lain & - & 0,750 & 1 & $c \times d x \in x 0,25$ \\
\hline
\end{tabular}

Keterangan : Tingkat Kecernaan Diperhitungkan $25 \%$

Sumber : Balitnak Ciawi Bogor (2006) 


\section{Populasi Ternak Ruminansia dan Kebutuhan Pakannya}

Kebutuhan pakan minimum dari kewan (ternak) pemakan hijauan persatuan ternak (satu ST) dapat dihitung sebagai berikut: (Tabel 3)

$\mathrm{K}=2,5 \% \times 50 \% \times 365 \times 250 \mathrm{~kg}$

$=1,14$ ton BKC/tahun/ST

Kemampuan Wilayah (ST)

$=$ IDD $x \quad$ Total Populasi (ST)

Kapasitas Penambahan Temak (ST)

$=$ Kemampuan Wilayah Populasi Ruminansia

3. Analisis Kapasitas Peningkatan Populasi Ternak Ruminansia (Nell dan Rollinson) a). Potensi Maksimum berdasarkan Sumberdaya Alam/PSLM (Daya Dukung Wilayah) dirumuskan :

PSLM = Daya Dukung Lahan Pertanian + Daya Dukung Tanaman Pangan

b). Nilai KPPTR

KPPTR (SL) $=$ PSML - Popril

$\operatorname{KPPTR}(\mathrm{SL})=$ Kapasitas peningkatan populasi temak ruminansia (ST) berdasarkan sumberdaya alam. Untuk melakukan perhitungan KPPTR, Nell dan Rolinson memberikan ketentuan - ketentuan seperti yang terlihat pada Tabel 4 dan 5.

Tabel 3. Kebutuhan Pakan Minimun Temak

\begin{tabular}{clccc}
\hline No. & Jenis Ternak & Jumlah & Faktor Konversi & Jumlah (ST) \\
\hline 1. Sapi & - & 0,70 & (c) $\times$ (d) \\
2. Kerbau & - & 0,80 & (c) $\times$ (d) \\
3. Domba & - & 0,06 & (c) $\times$ (d) \\
4. Kambing & - & 0,05 & (c) $\times$ (d)
\end{tabular}

Sumber : Balitnak Ciawi Bogor (2006)

Tabel 4. Kemampuan Lahan Dalam Menghasilkan Rumput

\begin{tabular}{lc}
\hline Jenis Lahan & Kontribusi Lahan (Ha) dalam \% \\
\hline Padang Rumput & 100 \\
Sawah & 2 \\
Galengan Sawah & 2,5 \\
Perkebunan & 5 \\
Hutan & 5 \\
Tepian Jalan & 0,5 \\
Tegalan & 1 \\
\hline Sumber: Nell dan Rollinson (1974) &
\end{tabular}


Tabel 5. Produksi Hijauan Makanan Ternak yang Dihasilkan dari Luas Panen

\begin{tabular}{lc}
\hline Hasil Limbah & Produksi Jerami (Ton BK/Ha/Tahun) \\
\hline Jerami Padi & 0,23 \\
Jerami jagung & 10,9 \\
Jerami ubi kayu & 5,05 \\
Jerami ubi jalar & 1,20 \\
Jerami kedelai & 1,07 \\
Jerami kacang tanah & 1,44 \\
\hline
\end{tabular}

Sumber : Nell dan Rollinson (1974)

\section{Hasil Dan Pembahasan}

\section{A. Keadaan Umum Sumatera Barat}

Provinsi Sumatera Barat mempunyai posisi yang sangat strategis. Sejumlah alasan menyertainya, secara geografis sebagai daerah penyebaran dan pertumbuhan penduduk. Kemudian produksi hasil pertanian (termasuk peternakan) dan pertumbuhan pemanfaatan sumber daya alam lainnya.

\section{B. Karakteristik Potensi Sumber Daya Alam Untuk Pengem- bangan Usaha Sapi Potong.}

Provinsi Sumatera Barat mempunyai luas wilayah $42.297,30$ $\mathrm{km}^{2}$ dari lahan tersebut dipergunakan untuk keperluan sebagai berikut :

\section{Potensi Bahan Pakan Yang Ada di Sumatera Barat}

\section{a) Berdasarkan Indelcs Dave Dukung}

1. Lahan Pertanian yang Potensial dalam Menghasilkan Pakan Hijauan (HMT)

Lahan - lahan pertanian yang dapat menyediakan HMT dapat diperoleh dari sawah, lahan kering, perkebunan, pekarangan, tegalan/ kebun, ladang, hutan rakyat, pagar hidup, dan lainnya. Dari hasil pengolahan data diperoleh total kontribusi lahan pertanian sebesar 1.888.032,77 ton/Ha/BKC.

2. Limbah Pertanian Asal Tanaman Pangan Sebagai Sumber Pakan

Limbah pertanian yang dapat dimanfaatkan sebagai pakan ternak dapat diperoleh dari tanaman pangan seperti padi sawah, padi ladang, jagung kedelai, kacang hijau, kacang tanah, ubi jalar dan ubi kayu.

Dari pengolahan data tersebut dapat diketahui bahwa tanaman pangan yang ada dapat menghasilkan limbah pertanian yang dapat dijadikan pakan ternak yakni sebesar $459.041,026$ ton BKC/tahun.

Setelah diketahui total ketersediaan pakan asal lahan pertanian dan pakan asal tanaman pangan, maka didapatkan total keseluruhan ketersediaan pakan di Sumatera Barat yaitu sebanyak 2.345.981,644 ton $\mathrm{BKC} /$ tahun.

3. Populasi Temak Ruminansia dan Kebutuhan Pakannya

Populasi Ternak Ruminansia di Sumatera Barat pada tahun 2005 adalah sebanyak $466.072,7 \mathrm{ST}$. Tabel 6 memuat rincian kebutuhan pakan ternak ruminansia di Sumatera Barat. 
Tabel 6. Kebutuhan Pakan Temak Ruminansia Per Kabupaten/Kota

\begin{tabular}{|c|c|c|c|c|c|c|}
\hline \multirow{2}{*}{ No. } & \multirow{2}{*}{ Kabupaten/Kota } & \multicolumn{4}{|c|}{ Kebutuhan Pakan (Ton BKC)/Thn } & \multirow{2}{*}{$\begin{array}{c}\text { Jumiah } \\
\text { Ton BKC } \\
\text { Thn } \\
\end{array}$} \\
\hline & & Sapi & Kerbau & Domba & Kambing & \\
\hline & Kabupaten & & & & & \\
\hline 1 & Kep. Mentawai & $1,589,60$ & 119,50 & - & 33,50 & $1.742,60$ \\
\hline 2 & Pesisir Selatan & $63.378,80$ & $28.300,30$ & - & $1.472,30$ & $93.151,40$ \\
\hline 3 & Solok & $32.275,90$ & $8,683,20$ & 4,50 & 744,80 & $41.708,40$ \\
\hline 4 & Swl / Sijunjung & $29.028,90$ & $30.914,98$ & 205,40 & $1.561,00$ & $61.710,28$ \\
\hline 5 & Tanah Datar & $34.467,20$ & $15.591,60$ & 1,00 & $1.291,96$ & $51.351,72$ \\
\hline 6 & Padang Pariaman & $44.734,30$ & $32.880,30$ & - & $1.429,60$ & $79.044,20$ \\
\hline 7 & Agam & $22.241,90$ & $15.934,50$ & - & 729,60 & $38.906,00$ \\
\hline 8 & 50 Kota & $41.847,10$ & $21.932,70$ & - & $1.100,50$ & $64.880,30$ \\
\hline 9 & Paseman & $7.090,20$ & $2.692,20$ & 26,10 & 387,90 & $10.196,40$ \\
\hline 10 & Solok Selatan & $4.483,20$ & $7.966,30$ & - & 385,70 & $12.835,20$ \\
\hline II & Dharmasraya & $10.920,60$ & $6.732,40$ & 17,90 & 598,30 & $18.269,20$ \\
\hline \multirow[t]{2}{*}{12} & Pasaman Barat & $8.311,20$ & $3.259,50$ & 6,30 & 479,90 & $12.056,90$ \\
\hline & Kota & & & & & - \\
\hline 13 & Padang & $18.564,70$ & $4.569,10$ & 149,80 & $1.097,80$ & $24.381,40$ \\
\hline 14 & Solok & $3.640,50$ & 253,10 & - & 139,94 & $4.033,54$ \\
\hline 15 & Sawahlunto & $5.046,60$ & $2.207,04$ & - & 203,95 & $7,457,59$ \\
\hline 16 & Padang Panjang & 608,10 & 110,60 & - & 18,00 & 736,71 \\
\hline 17 & Bukittinggi & 395,80 & 298,70 & - & 22,10 & 716,60 \\
\hline 18 & Payakumbuh & $5.733,60$ & 779,80 & - & 271,60 & $6.785,00$ \\
\hline 19 & Pariaman & 864,70 & 470,80 & 3,10 & 32,03 & $1.370,63$ \\
\hline \multicolumn{2}{|c|}{ Total Kebutuhan Pakan } & $333.633,30$ & $183.696,60$ & 414,10 & $12.000,50$ & $531.334,10$ \\
\hline
\end{tabular}

Tabel 6 diatas menjelaskan bahwa total kebutuhan pakan temak ruminansia selama satu tahun adalah sebesar $531,334,10$ ton BKC. Hal ini menunjukkan bahwa Sumatera Barat berdasarkan potensi ketersediaan pakannya masih bisa mendukung pemenuhan kebutuhan berupa rumput dan limbah pertanian. Rincian tiap kabupaten dan kota ada pada Tabel 7.
Kategori masing masing kabupaten /kota menurut IDD adalah sebagai dibawah ini.

1. Wilayah kritis $(1<\mathrm{IDD}<1,5$ : Kota Padang dan Kota Solok (IDD 1,41 dan 1,27),

2. Wilaysh rawan $(1,5<\operatorname{IDD} \leq 2)$ : Kab Tanah datar dan kota Payakumbuh (IDD 1,92 dan 1,64), 
3. Wilayah aman (IDD > 2) : Kab. Kep. Mentawai, Kab. Pesisir Selatan, Kab. Solok, Kab. Sawah Lunto/Sijunjung, Kab. Padang Pariaman, Kab. Agam, Kab. 50
Kota, Kab. Pasaman, Kab. Solok Selatan, Kab. Dharmasraya, Kab. Pasaman Barat, Kota Sawahlunto, Kota Padang Panjang. Kota Bukittinggi, dan Kota Pariaman.

Tabel 7. Nilai IDD Masing-masing Kabupaten/Kota di Sumatera Barat

\begin{tabular}{|c|c|c|c|c|}
\hline No & Kabupaten/Kota & IDD & $\begin{array}{c}\text { Total Persedian Pakan } \\
\text { (BKC Ton/Thn) }\end{array}$ & $\begin{array}{l}\text { Total Kebutuhan } \\
\text { (BKC Ton/Thn) }\end{array}$ \\
\hline & Kabupaten & & & \\
\hline 1 & Kep Mentawai & 97,07 & $169.152,00$ & $1.742,60$ \\
\hline 2 & Pesisir Selatan & 2,71 & $252.186,90$ & $93.151,40$ \\
\hline 3 & Solok & 3,81 & $158.900,10$ & $41.708,40$ \\
\hline 4 & Swl/ Sijunjung & 2,19 & $135.389,62$ & $61.710,28$ \\
\hline 5 & Tanah Datar & 1,92 & $98.765,70$ & $51.351,70$ \\
\hline 6 & Padang Pariaman & 2,36 & $186.296,10$ & $79.044,20$ \\
\hline 7 & Agam & 5,02 & $195.158,90$ & $38.906,00$ \\
\hline 8 & 50 Kota & 2,38 & $154.185,10$ & $64.880,30$ \\
\hline 9 & Pasaman & 16,13 & $164.488,50$ & $10.196,40$ \\
\hline 10 & Solok Selatan & 10,63 & $136.442,40$ & $12.835,20$ \\
\hline 11 & Dharmasraya & 11,51 & $210.279,50$ & $18.269,20$ \\
\hline \multirow[t]{2}{*}{12} & Pasaman Barat & 33,29 & $401.422,80$ & $12.056,90$ \\
\hline & $\underline{\text { Kota }}$ & & & \\
\hline 13 & Padang & 1,41 & $34.355,70$ & $24.381,40$ \\
\hline 14 & Solok & 1,27 & $5.119,10$ & $4.033,50$ \\
\hline 15 & Sawahlunto & 2,01 & $15,006,58$ & $7.457,59$ \\
\hline 16 & Padang Panjang & 2,99 & $2.203,30$ & 736,70 \\
\hline 17 & Bukittinggi & 2,29 & $1.643,10$ & 716,60 \\
\hline 18 & Payakumbuh & 1,64 & $11.157,80$ & $6.785,00$ \\
\hline \multirow[t]{2}{*}{19} & Pariaman & 10,16 & $13.828,50$ & $1,360,60$ \\
\hline & Total & 210,80 & $2.345 .981,70$ & $531.324,10$ \\
\hline
\end{tabular}

Sumber : Hasil Pengolahan Data (2007) 


\section{b) Menurut Nell dan Rollinson (1974)}

1. Lahan potensial untuk menghasilkan HMT

Lahan yang dapat menyediakan HMT di Sumatera Barat yaitu antara lain dapat bersumber dari lahan padang rumput, sawah, hutan, perkebunan dan tegalan

Dari hasil pengolahan data diketahui bahwa total produksi hijauan yang potensial dalam menghasilkan HMT yaitu sebanyak 33.286.255,20 ton/tahun. Untuk kebutuhan pakannya, 1 ekor sapi ternak membutuhkan hijauan sebanyak 12.775 ton /tahun, sehingga didapatkan daya dukung ternak terhadap hijauan sebanyak 2.605.577,71 ST. Dilihat dari jumlah ternak secara keseluruhan yang ada di Sumatera Barat menghabiskan hijauan sebanyak $5.357 .221,8$ ton/ tahun. Dari pakan yang tersedia masih tersisa sebanyak $27.929 .033,4$ ton/thn.

Dibandingkan dengan daya dukung ternak dan pakan yang tersedia masih bisa dipelihara sebanyak 2.605.577,706 ST, sedangkan ternak sapi yang ada atau dipelihara petani sebanyak 419.352 ekor. Dari data jumlah ternak sapi sekarang masih berpotensi untuk dilakukan penambahan ternak sapi di Sumatera Barat sebanyak 2.186.225.706 ST.

2. Limbah Pertanian Asal Tanaman Pangan sebagai Sumber Pakan

Total produksi limbah pertanian yang berasal dari tanaman pangan berdasarkan luas panennya sebesar $588.638,72$ ton

\section{Ketersediaan Bahan Pakan Untuk Sapi Potong.}

\section{a) Berdassrkan Indeks Daya Dukung}

Tabel 8, menyajikan kapasitas penambahan populasi temak ruminansia berdasarkan sumberdaya alam di Sumatera Barat adalah sebesar $562.863,2$ ST. Hal tersebut diperoleh dari kemampuan wilayah dikurangi populasi Ruminansia.

Dengan mengetahui perbandingan persentase populasi ternak ruminansia, dapat diketahui kapasitas peningkatan populasi tiap jenis temak ruminansia yang ada, termasuk sapi potong. Tabel 9 menampilkan perbandingan kapasitas penambahan ternak ruminansia berdasarkan ketersediaan pakannya.

Berdasarkan perbandingan populasi ternak ruminansia yang ada di Sumatera Barat, maka didapatkan nilai untuk peningkatan kapasitas ternak sapi potong adalah sebesar $335.110,6$ ST. Hal ini menujukkan bahwa Sumatera Barat berdasarkan sumberdaya alam masih berpotensi untuk mendukung penambahan populasi ternak sapi potong sebesar nilai tersebut.

\section{b. Menurut Nell dan Rollinson (1974)}

1. Potensi Maksimum Daya Dukung Sumatera Barat Berdasarkan Sumber Daya Alam.

Daya Dukung/PSML menentukan seberapa banyak satuan ternak ruminansia yang dapat didukung oleh suatu wilayah berdasarkan potensi pakan yang dapat disediakan diwilayah tersebut. Dari hasil penelitian diperoleh total daya dukung lahan pertanian sebesar $2.605 .577,7$ ST, dan total daya dukung limbah asal tanaman pangan sebesar 255.929,88 ST sehingga diperoleh total daya dukung sebesar 
2.861.507,58 ST. Hal ini berarti Sumatera Barat masih masih berpotensi dikembangkan ternak sapi potong berdasarkan potensi pakan yang tersedia.

2. Kapasitas Peningkatan Populasi Temak Ruminansia berdasarkan Sumberdaya Alam (KPPTR SL)
Dengan mengetahui daya tampung wilayah Sumatera Barat, dapat dihitung kapasitas peningkatan populasi ternak ruminansia berdasarkan sumberdaya alam. Dari pengolahan data, nilai total Kapasitas Peningkatan Populasi Ternak Ruminansia berdasarkan Sumberdaya Alam (KPPTR SL) di Sumatera Barat adalah $2.233 .590,99 \mathrm{ST}$.

Tabel 8. Kemampuan Wilayah dan Kapasitas Penambahan Ternak Ruminansia di Sumatera Barat

\begin{tabular}{|c|c|c|c|c|}
\hline No & Kabupaten/Kota & $\begin{array}{c}\text { Kemampuan } \\
\text { Wilayah } \\
\text { (ST) }\end{array}$ & $\begin{array}{c}\text { Populasi } \\
\text { Ruminansia } \\
\text { (ST) }\end{array}$ & $\begin{array}{c}\text { Kapasitas } \\
\text { Penambahan } \\
\text { (ST) }\end{array}$ \\
\hline & Kabupaten & & & \\
\hline 1 & Kep Mentawai & $74.189,70$ & $1.528,60$ & $72.661,10$ \\
\hline \multirow[t]{2}{*}{2} & Pesisir Selatan & $110.608,10$ & $81.711,70$ & $28.896,50$ \\
\hline & Solok & $69.692,90$ & $36.586,30$ & $33.106,70$ \\
\hline 4 & Swl / Sijunjung & $59.381,40$ & $54.131,78$ & $5.249,60$ \\
\hline 5 & Tanah Datar & $43.318,20$ & $45.045,34$ & $-1.727,10$ \\
\hline 6 & Padang Pariaman & $81.708,90$ & $69.337,10$ & $12.371,80$ \\
\hline 7 & Agam & $85.595,80$ & $34.128,00$ & $51.467,80$ \\
\hline 8 & $50 \mathrm{Kota}$ & $67.625,10$ & $56.912,60$ & $10.712,50$ \\
\hline 9 & Pasaman & $72.145,00$ & $8.944,30$ & $63.200,60$ \\
\hline 10 & Solok Selatan & $59.842,90$ & $11.258,90$ & $48.584,00$ \\
\hline 11 & Dharmasraya & $92.227,50$ & $16.025,60$ & $76,202,00$ \\
\hline \multirow[t]{2}{*}{12} & Pasaman Barat & $176.060,60$ & $10.576,10$ & $165.484,50$ \\
\hline & Kota & & & \\
\hline 13 & Padang & $15.068,30$ & $21.387,20$ & $-6.318,90$ \\
\hline 14 & Solok & $2.244,90$ & $3.537,75$ & $-1.292,80$ \\
\hline 15 & Sawahlunto & $6.581,80$ & $6.541,70$ & 40,10 \\
\hline 16 & Padang Panjang & 966,00 & 646,00 & 320,00 \\
\hline 17 & Bukittinggi & 721,10 & 629,00 & 92,10 \\
\hline 18 & Payakumbuh & $4.893,80$ & $5.952,00$ & $-1.058,00$ \\
\hline \multirow[t]{2}{*}{19} & Pariaman & $6.063,90$ & $1.193,30$ & $4.870,60$ \\
\hline & Total & $1.028 .935,90$ & $466.072,70$ & $562.863,20$ \\
\hline
\end{tabular}

Sumber : Hasil Pengolahan Data (2007) 
Tabel 9. Perbandingan Persentase Populasi Ternak Ruminansia

\begin{tabular}{|c|c|c|c|c|c|c|}
\hline \multirow{2}{*}{ No. } & \multirow{2}{*}{ Kabupaten/Kota } & \multicolumn{4}{|c|}{ Ternak Ruminansia } & \multirow{2}{*}{ Total } \\
\hline & & Sapi & Kerbau & Domba & Kambing & \\
\hline & Kabupaten & & & & & \\
\hline 1 & Kepulauan Mentawai & $1.394,40$ & 104,80 & - & 29,40 & $1.528,60$ \\
\hline \multirow[t]{2}{*}{2} & Pesisir Selatan & $55,595,40$ & $24.824,80$ & - & $1.291,45$ & $81,711,65$ \\
\hline & Solok & $28.312,20$ & $7.616,80$ & 3,96 & 653,30 & $36.586,26$ \\
\hline 4 & Swl / Sijunjung & $25,463,90$ & $27.118,40$ & 180,18 & $1.369,30$ & $54,131,78$ \\
\hline 5 & Tanah Datar & $30.234,40$ & $13.676,80$ & 0,84 & $1.133,50$ & $45.045,54$ \\
\hline 6 & Padang Pariaman & $39.240,60$ & $28.842,40$ & - & $1.254,05$ & $69.337,05$ \\
\hline 7 & Agam & $19.510,40$ & $13.977,60$ & - & 640,00 & $34.128,00$ \\
\hline 8 & $50 \mathrm{Kota}$ & $36.708,00$ & $19.239,20$ & - & 965,35 & $56.912,55$ \\
\hline 9 & Pasaman & $6.219,50$ & $2.361,60$ & 22,90 & 340,30 & $8.944,30$ \\
\hline 10 & Solok Selatan & $3.932,60$ & $6.988,00$ & - & 338,30 & $11.258,90$ \\
\hline 11 & Dharmasraya & $9.579,50$ & $5.905,60$ & 15,70 & 524,80 & $16,025,60$ \\
\hline \multirow[t]{2}{*}{12} & Pasaman Barat & $7.290,50$ & $2.859,20$ & 5,50 & 420,95 & $10.576,20$ \\
\hline & Kota & & & & & - \\
\hline 13 & Padang & $16.284,80$ & $4.008,00$ & 131,40 & 962,95 & $21.387,15$ \\
\hline 14 & Solok & $3.193,40$ & 222,00 & - & 122,75 & $3.538,15$ \\
\hline 15 & Sawahlunto & $4.426,80$ & 1936,00 & - & 178,90 & $6.541,70$ \\
\hline 16 & Padang Panjang & 533,40 & 97,00 & - & 15,80 & 646,00 \\
\hline 17 & Bukittinggi & 347,20 & 262,00 & - & 19,35 & 628,60 \\
\hline 18 & Payakumbuh & $5.029,50$ & 684,00 & - & 238,25 & $5.951,75$ \\
\hline 19 & Pariaman & 749,70 & 413,00 & 2,70 & 28,10 & $1.193,50$ \\
\hline \multicolumn{2}{|c|}{ Total (ST) } & $294.046,20$ & $161.137,20$ & 363,20 & $10.526,80$ & $466.073,38$ \\
\hline \multicolumn{2}{|c|}{ Persentase } & 63,09 & 34,57 & 0,08 & 2,26 & 100 \\
\hline \multicolumn{2}{|c|}{ Kemampuan Wilayah (ST) } & 649.157 & 355.703 & 823,10 & $23.254,95$ & $1.028 .937,9$ \\
\hline \multicolumn{2}{|c|}{ Kapasitas Penambahan } & $355.110,60$ & $194.565,90$ & 459,90 & $12.728,20$ & $562.864,50$ \\
\hline
\end{tabular}


Tabel 10. Perbandingan KPPTRSL

\begin{tabular}{|c|c|c|c|c|c|}
\hline Kabupaten/Kota & Sapi & Kerbau & Kambing & Domba & Total ST \\
\hline \multicolumn{6}{|l|}{ Kabupaten } \\
\hline Kep Mentawai & $1.881,44$ & 131 & 82,32 & - & $2.094,76$ \\
\hline Pesisir Selatan & $75.014,07$ & 31.031 & $3.616,06$ & - & $109.661,14$ \\
\hline Solok & $38.201,25$ & 9.521 & $1.829,24$ & 9,24 & $49.560,73$ \\
\hline Swl / Sijunjung & $34.358,08$ & 33.898 & $3.834,04$ & 420,42 & $72.510,54$ \\
\hline Tanah Datar & $40.622,01$ & 17.096 & $3.173,24$ & 1,96 & $60.893,20$ \\
\hline Padang Pariaman & $52.946,78$ & 36.053 & $3.511,34$ & - & $92.511,12$ \\
\hline Agam & $26.297,71$ & 17.472 & $1.792,00$ & - & $45.561,71$ \\
\hline 50 Kota & $49.474,80$ & 24.049 & $2.702,98$ & - & $76.226,78$ \\
\hline Pasaman & $8.390,88$ & 2.952 & 952,84 & 53,48 & $12.349,20$ \\
\hline Solok Selatan & $5.306,20$ & 8.735 & 947,24 & - & $14.988,44$ \\
\hline Dharmasraya & $12.922,65$ & 7.382 & $1.469,44$ & 36,54 & $21.810,63$ \\
\hline Pasaman Barat & $9.836,97$ & 3.574 & $1.178,66$ & 12,74 & $14.602,37$ \\
\hline \multicolumn{6}{|l|}{ Kota } \\
\hline Padang & $21.783,95$ & 5.110 & $2.696,26$ & 306,60 & $29.896,81$ \\
\hline Solok & $4,308,81$ & 277 & 343,70 & $=$ & $4.929,51$ \\
\hline Sawahlunto & $5.973,02$ & 2,420 & 500,92 & - & $8,893,94$ \\
\hline Padang Panjang & 498,70 & 121 & 44,24 & - & 663,94 \\
\hline Bukittinggi & 459,03 & 328 & 54,18 & - & 841,21 \\
\hline Payakumbuh & $6.786,23$ & 855 & 667,10 & - & $8.308,33$ \\
\hline Pariaman & $1.011,26$ & 516 & 78,68 & 6,30 & $1.612,24$ \\
\hline Total (ST) & $396.073,83$ & 201.521 & $29.474,50$ & 847,28 & $627.916,59$ \\
\hline Persentase (\%) & 63,08 & 32,09 & 4,69 & 0,14 & 100,00 \\
\hline KPPTR SL (ST) & $1.408 .892,45$ & 716.840 & $104.845,03$ & $3.013,90$ & $2.233 .590,99$ \\
\hline
\end{tabular}

Sumber : Hasil Pengolahan Data (2007)

Dengan mengetahui perbandingan populasi rill ternak ruminansia dapat diketahui kapasitas peningkatan populasi masing masing jenis ternak ruminansia yang ada di Sumatera Barat termasuk sapi potong. Dengan total ST 2.233.590,99, dan persentase populasi sapi potong $63 \%$, maka diperoleh kapasitas penambahan ternak sapi potong sebesar $1.408 .892,446$, seperti terlihat pada Tabel 10.

Perbedaan hasil antara kedua metode disebabkan karena adanya perbedaan dalam jenis lahan. Nell \& Rollinson memasukkan potensi dari kawasan hutan, sedangkan IDD tidak memperhitungkannya. Untuk aplikasi 
di Sumatera Barat, faktor perbedaan diatas cukup memberi alasan. Sebab, topografi kawasan yang bergelombang dan berbukit - bukit. Berdasarkan kondisi tersebut memang sangat sulit untuk menggunakan metode Nell \& Rollinson untuk daerah Sumatera Barat.

Berdasarkan pandangan dan peluang aplikasi lapangan diatas cukup beralasan pula untuk lebih menggunakan metode IDD. IDD untuk wilayah Sumaters Barat lebih realistis untuk ditindak lanjuti.

\section{Kesimpulan Dan Saran}

\section{A. Kesimpulan}

Dari hasil penelitian yang dilakukan dapat diambil kesimpulan bahwa daerah ini memiliki potensi yang dapat menunjang dalam pengembangan usaha sapi potong ditinjau dari aspek sumberdaya alam/ketersediaan pakan hijauan maupun pakan limbah pertanian.

Dari metoda IDD, Nell dan Rollinson terlihat bahwa Sumatera Barat memiliki sumber bahan pakan sebesar 1.888.032,77 Ton BKC dari ketersediaan pakan asal pertanian dan 459.041,026 ton BKC dari limbah pertanian asal tanaman pangan (IDD) serta diperoleh juga total produksi hijauan dan total produksi limbah pertanian masing-masing sebesar $\quad 33.286 .255,20$ dan $588.638,72$ ton/ tahun (Nell dan Rollonson 1974)

Dengan kemampuan wilayah Sumatera Barat sebesar 1.028.935.9 ST dan Populasi Ruminansia yang ada sebesar 446.072,7 ST maka didapatkan Kapsaitas penambahan ternak sebesar $562.863,2$ ST dimana $63 \%$ dari kapasitas penambahan tersebut adalah temak sapi yaitu sebesar 355.110,6 ST (menurut IDD), sedangkan menurut Nell dan Rollinson didapatkan hasil bahwa Sumatera Berat memiliki Daya Dukung (PSML) sebesar 2.861.507,58 ST dimana Populasi Riil ternak tersebut sebesar $627.916,593$ sehingga diperoleh nilai KPPTR SL 2.233.590,99 ST, $63 \%$ dari kapasitas penambahannya adslah ternak sapi yaitu sebesar 1.408.892,446. Berdasarkan kepada kondisi wilayah Sumatera Barat yang bergelombang dan berbukit - bukit maka metode IDD lebih realistis untuk ditindak lanjuti.

\section{B. Saran}

Keberadaan potensi sumber bahan pakan untuk pengembangan usahu sapi potong di Sumatera Barat dijadikan bahan pertimbangan dalam upaya pengembangan lebih lanjut. Sesuai dengan visi pemerintah daerah Sumatera Barat untuk menjadikan Sumatera Barat sebagai pusat pangan asal ternak di Sumatera Bagian Tengah tahun 2010. Dari perkiraan, kiranya daya dukung pengembangan ternak sapi masih mampu sampai dua dekade kedepan.

\section{Daftar Pustaka}

Abidin, Z. 2002. Penggemukan Sapi Potong. Penerbit Agro Media Pustakn, Jakarta.

Ashari, Sumanto, E Juarni, B Wibowo. 1996, Petunjuk Pelaksanaan Analisis Potensi Wilayah Penyebaran dan Pengembangan Peternakan. Kerjasama Dit.Jen.NakBalitnak 1996, Bogor.

Badan Pusat Statistik Sumatera Barat. 2005.Sumatera Barat Dalam Angka, Sumatera Barat. 
Dinas Peternakan Propinsi Sumatera Barat. 2005. Populasi Ternak Sapi Potong dan Jumlah Pemotongan Ternak, Padang.

Direktorat Jendral Peternakan. 1985. Usaha Peternakan, Perencanaan Usaha, Analisa dan Pengelolaan. Direktorat Bina Usaha Petani Ternak dan Pengolahan Hasil Peternakan, Jakarta.

Direktorat Jendral Peternakan. 2003, Buku Statistik Peternakan. Direktorat Bina Penyebaran dan Peternakan, Jakarta.

Pengembangan Darmono. 1992. Tata laksana Usaha Sapi Kereman. Penerbit Kanisius, Jakarta.

Nell, A.J dan D.H. I. Rollinson. 1974. The Requirement and Availability of Livestock Feed in Indonesia. UNDP Project INS/72/009.

Sumarno dan Juarini E. 2006. Pedoman Identifikasi Wilayah. Badan Penelitian Ternak, Bogor.

Alamat korespondensi: Dr. Ir. Fuad Madarisa M.Sc,

Jurusan Produksi Ternak, Fakultas Peternakan

Universitas Andalas, Kampus Limau Manis, Padang

Telp. 0751-74208 Fax: 0751-71464, HP; 08126604713

Diterima: 15 Agustus 2007, Disetujui: 6 September 2007 